\title{
Religião em movimento: Interpretação da Bíblia no cinema
}

\author{
Religion in movement: interpretation of the Bible in \\ Cinema
}

\section{Religión en movimiento: interpretación de la Biblia en el Cine}

\author{
Prof. Dr. Paulo Augusto de \\ Souza Nogueira*
}

Submetido em: 26-03-2021

Aceito em: 06-05-2021

\author{
* Pontifícia Universidade Católica de \\ Campinas, PPG - Ciências da Religião \\ pasn777@gmail.com
}

\begin{abstract}
RESUMO
Este artigo propõe uma discussão sobre as relações entre cinema e religião, mais especificamente, entre a linguagem cinematográfica e a literatura bíblica. Propomos que, além de uma relação de correlação, o cinema seja um articulador e potencializador da polissemia dos textos bíblicos. Isso se dá a partir de três fatores: a) a linguagem onírica do filme, análoga à da narrativa religiosa; b) o caráter semioticamente híbrido do filme e sua consequente polifonia; e c) o espaço mágico e mito-poético que o filme proporciona para experiências de projeção e identificação dos espectadores. Por fim, procedemos a uma análise dos eixos bíblicos e mito-poéticos no filme Metropolis (1927), dirigido por Fritz Lang, na qual buscamos evidenciar as possibilidades não só de reconhecer sua ação estruturadora do filme, como também a ativação de novas conexões e associações na interpretação do texto bíblico. Palavras-chave: Cinema e religião; cinema e literatura bíblica; interpretação contemporânea da Bíblia; polissemia dos textos religiosos.
\end{abstract}

\begin{abstract}
This article intends to discuss the relations between film and religion, and specifically, between film and biblical literature. We propose that beyond the correlation principle, the film articulates and potentializes the polysemy of the biblical texts. This happens due to three factors: a) the oneiric language of the film, analogous to the biblical narrative; b) the semiotically hybrid characteristic of the movie, and its consequent polyphony, and c) the magic and myth-poetic space that the film enhances, making possible for the spectators to proceed to projections and identifications. And finally, we offer an analysis of biblical and myth-poetic axes in the movie Metropolis (1927), directed by Fritz Lang, where we try to make visible their structuring action in the film, but also the activation of new connections and associations in the interpretation of the biblical text.

Keywords: Film and religion; film and biblical literature; contemporary interpretation of the Bible; polysemy of the religious texts.

\section{RESUMEN}

Este artículo propone una discusión sobre las relaciones entre cine y religión, más específicamente, entre lenguaje cinematográfico y literatura bíblica. Proponemos que, más allá de una relación de correlación, el cine es un articulador y potenciador de la polisemia de los textos bíblicos. Esto se da a partir de tres factores: a) el lenguaje onírico de los films análogo a las narrativas religiosas; b) el carácter semiótico híbrido del film y su consecuente
\end{abstract}


polifonía; y c) el espacio mágico y mito- poético que el film proporciona para las experiencias proyectivas e identificatorias de los espectadores. Para finalizar, procederemos a un análisis de los ejes bíblicos y mito- poéticos en el film Metropolis(1927), dirigido por Fritz Lang , en el que buscamos evidenciar las posibilidades de la acción estructuradora del film, como también reconocer la activación de nuevas conexiones y asociaciones de la interpretación del texto bíblico.

Palabras-clave: Cine y religión; cine y literatura bíblica; interpretación contemporânea de la Bíblia; polisemia de los textos religiosos.

\section{Cinema: acesso ao texto bíblico?}

Os estudos sobre as relações entre cinema e religião e entre cinema e estudos bíblicos, em especial, não são novidade. Já há uma quantidade considerável de estudos sobre a forma como os filmes recriam temas religiosos e como eles impactam nos modos das pessoas experimentarem religião. Nessa relação entre cinema e religião, no ocidente, a Bíblia ocupa uma posição privilegiada, uma vez que as narrativas fundantes do cristianismo provêm do Antigo e do Novo Testamento. Por isso, na área de estudos bíblicos, contamos com publicações especializadas sobre cinema e Bíblia como, por exemplo, a exaustiva e especializada obra The Bible in Motion: A Handbook of the Bible and Its Reception in Film, editada por Burnette-Bletsch (2016). ${ }^{1}$

Muitos desses esforços, no entanto, estão dedicados principalmente a estabelecer relações temáticas. Como um texto bíblico é adaptado e recriado no filme? Que implicações hermenêuticas e ideológicas advêm dessas adaptações? Não podemos nos esquecer que muitas dessas produções cinematográficas tiveram forte impacto na imaginação religiosa de milhões de pessoas em todo o globo. Impossível ignorar o sentimento de devoção dos espectadores ao assistirem uma das vidas de Cristo, nas telas dos cinemas e canais de TV aberta na Semana Santa. As narrativas bíblicas determinam o tema da narrativa cinematográfica. No entanto, essa relação se torna circular, pois, depois, ao ler a narrativa dos evangelhos, o espectador associará as imagens do filme à leitura que faz. A imaginação bíblica fica de alguma forma indissociada da imaginação do filme. Os filmes passam, desta forma, a determinar muito da experiência com o texto bíblico. E se o cristianismo é uma religião do livro, poderíamos afirmar que ela determina também a experiência religiosa. Nesse caso, estaríamos caminhando para uma religião do livro mediado por imagens cinematográficas?

\footnotetext{
Também merecem destaque as obras recentes que abordam a temática, como: SHEPHERD, D. (ed.). Images of the World: Hollywood's Bible and beyond (SBL Semeia Studies, v. 54). Leiden: Brill, 2008; EXUM, J. Cheryl (ed.). The Bible in Film. The Bible and Film. Leiden: Brill, 2006; REINHARDT, Adele (ed.). Bible and Cinema: fifty key films. London: Routledge, 2013, entre muitas outras.
} 
No ano de 2004, essa relação entre exibição de filmes de Jesus e devoção religiosa atingiu um nível ainda mais intenso com a obra dirigida por $\mathrm{Mel}$ Gibson, The Passion of the Christ, na qual havia uma busca por representar o mais literalmente possível os eventos narrados nos evangelhos sobre sua traição, julgamento, flagelo e crucificação. O realismo adotado pela direção do filme atingiu níveis até então desconhecidos, como na plasticidade da cena do flagelamento de Jesus pelos soldados romanos. Esse realismo extremo invadiu o espaço do simbólico, chegando inclusive a ameaçar substituí-lo. "Foi assim mesmo que aconteceu", exclamavam os espectadores. É sabido de comunidades religiosas no Brasil que alugaram salas de cinema para exibição privada, em caráter litúrgico, do filme. Podemos nos perguntar pelo poder imagético e emocional que essa exibição teria exercido sobre as comunidades extasiadas diante do "verdadeiro" sofrimento do Salvador que, com "aquelas" chagas e flagelos, pagou pelos seus pecados. Seria o filme, nesse caso, um facilitador da experiência religiosa, ou estaria ele criando um tipo novo de identificação? Quanto interfere essa mediação tecnológica na percepção do símbolo religioso? E de que maneira a articulação imagética de modelos de devoção determinam a recepção de sua proposta?

Não é apenas no âmbito das representações de narrativas e cenas bíblicas que o cinema impacta na experiência de percepção e interpretação. Criações ficcionais inspiradas em textos e temas bíblicos acabam adquirindo por vezes um caráter quase canônico. Pensemos na série de filmes Deixados para Trás (Left Behind, sendo o primeiro deles de 2000, dirigido por Vic Sarin), inspirada na série de livros homônima de Tim La Haye e Jerry B. Jenkins. Esse filme e os demais que se seguiram tiveram um impacto tão grande no universo evangélico brasileiro, que se tornaram uma espécie de lente por meio da qual o texto bíblico passou a ser interpretado. O papel dos filmes como mediação para a leitura e imaginação dos textos bíblicos é um tópico que deveria interessar não só à hermenêutica bíblica, mas também à crítica da ideologia religiosa do mundo contemporâneo, afinal, eles não são assistidos apenas por espectadores religiosos. Nos ambientes em que Deixados para Trás é oferecido como acesso normativo às ideias escatológicas da Bíblia e, principalmente, dos livros de Daniel e do Apocalipse de João, a bricolagem de textos proposta pela obra, compondo uma narrativa escatológica para tempos de Guerra Fria e além, fundiu-se ao texto bíblico. Também podemos afirmar que, apesar dos filmes serem produtos derivados das narrativas da série de livros, são os filmes que exerceram (no Brasil, pelo menos) poder de moldar imaginação e modelos de interpretação. Esse modelo é tão poderoso que qualquer trabalho de renovação da interpretação do livro de Daniel e 
do Apocalipse de João em comunidades formadas na escatologia literalista evangélica deve que começar com uma certa desmontagem dos pressupostos do filme, mostrar suas bricolagens grosseiras, e o poder da ideologia da Guerra Fria operando por detrás e por dentro das imagens. Apenas após certa demitização e alguma catarse é possível se voltar ao texto bíblico e criar com ele novas experiências de leitura.

Esse papel determinante do filme sobre a interpretação do texto não é meramente temático, como se o filme fosse uma recriação de temas pura e simplesmente. De fato, já na experiência de leitura do texto escrito nós experimentamos um processo semiótico fundamental de tradução das sequências discretas do texto em composições imagéticas mentais. Esse é, aliás, um dos fascínios da leitura: a ativação de processos dinâmicos de imaginação. Ao lermos as páginas de uma narrativa, criamos cenários, semblantes, recriamos cenas, e, no caso de textos com alta densidade simbólica, como os textos bíblicos, os associamos a estados emocionais e místicos. Quando, no entanto, esses textos são mediados por filmes com pretensões realistas e literais de representar o que realmente aconteceu - e esse é o caso também das ficções escatológicas, como "Deixados para Trás" - o processo de imaginação, da tradução do discreto ao icônico - já está feito. E essas visualizações já preparadas acompanham as articulações de sentido: no literal, nas sequências e nas associações. Nos casos mencionados acima, o contrato com o espectador é nada menos que o Cristo teria sido flagelado como mostrado nas imagens hiper-realistas, em tempo quase real, com sangue derramado e carne dilacerada quase que diante de nossos olhos. Os eventos e batalhas escatológicas nos são mostrados na tela como efetivamente acontecerão no futuro próximo.

Nossa breve exposição do problema da sobredeterminação da imagem cinematográfica sobre a imaginação religiosa não deve nos desencorajar de buscar possibilidades criativas e críticas na relação cinema e interpretação bíblica. Os exemplos que demos acima não devem nos fazer desistir do cinema, muito menos descartá-lo. Há possibilidades criativas e ativadoras de interpretação, que pretendemos explorar nesse ensaio. A exegese bíblica tradicional tem um perfil delimitado pela filologia e pelo historicismo. Segundo essa vertente canônica, um texto só pode ser interpretado nos seus parâmetros linguísticos, culturais e históricos do passado. E o sentido a ser resgatado pelas operações exegéticas tem pretensões de ser original. Nesse ponto, sentido do passado e sentido original se equivalem. Em relação a essa norma, as demais abordagens, quando toleradas, são classificadas como contextuais, complementares, ou, de forma mais generosa, chamadas de "recepção". Essa postura repousa sobre uma contradição fundamental: o texto 
bíblico teria um sentido oculto - não evidente - no passado; no entanto, esse sentido poderia ser alcançado exclusivamente por meio de ferramentas modernas, criadas no Iluminismo (os métodos exegéticos), capazes de resgatar o sentido do passado. Ou seja, o sentido do texto não seria evidente, não estaria acessível ao senso comum. Por isso, o uso de ferramentas especializadíssimas. Mas só elas teriam o poder de desvelar os sentidos do passado, originais. Mesmo as leituras antigas, dos pais da igreja, por exemplo, não passariam de aproximações, de "recepções".

Nossos pontos de partida são diferentes. Os textos bíblicos são compreendidos como polissêmicos: isso se deve à sua densidade narrativa, poética e simbólica. Nesse sentido, eles têm sentidos potenciais. Esses sentidos potenciais só podem ser ativados por meio de processos de leitura concretos, pelos mais diferentes sujeitos, na antiguidade ou em qualquer outro período histórico. ${ }^{2}$ Ainda que entendamos que os procedimentos de análise filológicos, literários e históricos sejam imprescindíveis, também entendemos que as ferramentas teórico-metodológicas criadas na modernidade devem dialogar com outras perspectivas de análise, não podendo ocupar uma posição de absoluta primazia hierárquica. Propomos, portanto, que na interpretação bíblica contemporânea os processos de interpretação do texto bíblico nos mais diferentes sujeitos e culturas, nas várias linguagens da religião e da arte, sejam igualmente valorizados. O texto do passado - um passado que é sempre uma hipótese, construída a partir de pressupostos - deve ser ativado por leitores do presente. É nesse encontro de texto e leitor que se dá a criação do sentido: do potencial polissêmico do texto às escolhas, interferências, redimensionamentos, cortes, acréscimos de leitores e leitoras concretos.

Se não devemos mais, por um lado, aceitar o primado dos métodos exegéticos tradicionais como a ferramenta exclusiva, oficial e autorizada de interpretação dos textos bíblicos, isso significa que devamos, por outro lado, aceitar que abordagens que analisem a narrativa cinematográfica desses textos tenham um papel de importância nos estudos bíblicos? Não seria o cinema, afinal, a arte mais técnica de todas, mais distante possível da "simplicidade" da escrita? Não seria o cinema uma arte particular e distante demais dos contextos religiosos de apropriação do texto bíblico? Nossa proposta neste artigo é precisamente que, devido à complexidade técnica e estruturação semiótica da linguagem cinematográfica, o cinema nos oferece um promissor acesso à criação de sentido no texto bíblico. Não queremos argumentar em

2 Desenvolvo melhor esses argumentos no artigo: "O conceito de texto, contexto e leitor na interpretação de textos religiosos: o caso da literatura bíblica”. In: Estudos de Religião, v.33, n.3, set.-dez. 2019, p. 175-190. Disponível em https://www.metodista.br/revistas/ revistas-ims/index.php/ER/article/view/9932. Acesso em 29 abr 2021. 
favor de qualquer inversão de hierarquias de abordagens, mas tão somente demonstrar a pertinência dos estudos sobre cinema e religião.

Há iniciativas recentes que merecem nossa atenção, como o livro Insights from Filmmaking for Analyzing Bliblical Narrative, de Gary Yamasaki, publicado em 2016. Nesta instigante obra, o autor transcende o interesse de analisar como personagens, cenas, temas e narrativas bíblicas são recriadas no cinema, propondo algo de fato inovador: usar a técnica de análise de filmes como método para entender o texto bíblico. Ou seja, trabalhar com a ideia de que obra cinematográfica e o texto bíblico são montados de forma análoga e que, portanto, podem ser analisados com os mesmos procedimentos.

Segundo Yamasaki (2016, p. 36), sua obra tem por pressuposto o fato que "ler um texto bíblico narrativo é semelhante a assistir um filme". Seu argumento tem uma fundamentação simples, mas convincente. Histórias da Bíblia e dos filmes, apesar de suas diferenças, refletem características básicas das narrativas. No entanto, somos muito mais expostos a narrativas fílmicas, o que quase nos "imprime no DNA" essa forma de perceber narrativa. Desta maneira, soa natural que analisemos as narrativas bíblicas como analisaríamos narrativas cinematográficas. Partindo desse pressuposto, o autor nos aponta para características básicas da narrativa cinematográfica que oferecerão a ele modelos de acesso às histórias bíblicas. Por exemplo, os filmes nos conduzem para experiências, eventos, de caráter afetivo. Desta forma, assistir a um filme faz com que certas regras se imponham à experiência, como o fato de que a história se desenrola na sequência da narração e da projeção, que o acesso aos dados do que foi narrado e projetado depende do alcance da memória espectador. Esse acúmulo de informação até certo momento determina a experiência que se pode ter dele. Yamasaki também nos remete à teoria de enredo, segundo a qual o enredo de um filme não equivale a uma lista de eventos. Da mesma forma, a caracterização dos personagens é dinâmica, nunca estática. Os detalhes de um filme são filtrados para os espectadores por meio de pontos de vista. Todos esses aspectos da apreciação de uma narrativa fílmica podem ser aplicados com proveito na análise de narrativas do Antigo e do Novo Testamento. Em nossa opinião, a proposta de Yamasaki é promissora, pois permitiria que gerações de jovens intérpretes moldados na linguagem audiovisual do cinema se voltem para as narrativas antigas, apreciando as características comuns entre os modelos. A forma comum da narrativa na Bíblia e no cinema justificaria o uso de perspectiva comum de análise e a maior familiaridade do intérprete contemporâneo com a narrativa audiovisual fundamentaria a proposta de começar a análise do texto antigo pelo modelo de análise do filme. 


\section{Cinema e linguagem onírica ${ }^{3}$}

O cinema é uma forma artística visual, que combina e articula seus elementos com liberdade frente ao real. Nele também a subjetividade do espectador participa das construções de sentido por meio de projeções e identificações. A interpretação psicanalítica do cinema como proposta metodológica não é nova, mas isso não faz com que seja frequente e efetiva o suficiente como prática. Antes, florescem as interpretações psicológicas dos personagens e as abordagens que se baseiam nos fatores anímicos e arquetípicos dos personagens. A psicanálise, no entanto, em sua vertente discursiva, oferece um método interpretativo das operações do texto para buscar novas significações, sem se limitar a abreviações cognitivas e de conduta que explicam os personagens. Seguem aqui algumas observações sobre essa abordagem do filme e suas possibilidades de explorar a relação com a religião e com a Bíblia.

Segundo a filósofa da religião Edith Wyschogrod (apud AICHELE, 1995, p. 199), o texto do inconsciente e o texto teológico são homólogos e estão abertos a uma estratégia interpretativa comum. O método proposto é o midráxico, uma vez que é central para a psicanálise que cada significante expresse o deslocamento de um significado, ou seja, que possibilita uma leitura distinta da esperada (LACAN, 1975). As técnicas da leitura midráxica, em sua busca do enigma que se esconde no texto, não outorgam um sentido fixo, nem unívoco aos versículos da Torá. Hillel pautou treze regras de interpretação literal do texto. Mencionaremos duas delas que estão em consonância com o método que elabora Freud na "A Interpretação dos Sonhos" (2020): a s'mubá evidencia que a justaposição de dois versículos de significado heterogêneo encontra um nexo lógico que permite lê-los como um só sintagma. De sua parte, a g'žerá shavá trata da contiguidade que permite tratar analogamente significados a partir de textos que compartilham um significado. Em ambas se realizam a tradução de significações e se recontextualizam campos textuais diversos.

Neste campo interpretativo, o sonho não é pura imagem, mas um rebus, uma adivinhação organizada na combinação de signos gráficos que oscilam entre a materialidade gráfica ou fonética e o sentido. No sonho há pensamento, nos diz Freud; ele tem leis próprias, distintas das da consciência. Ele é regido pelas lógicas do princípio de contradição e do terceiro excluído, e rompe com o princípio de identidade. O trabalho do sonho se apresenta na forma de enunciados fragmentários que, durante a vigília, são submetidos

3 Nesta parte do artigo eu tive a colaboração e debate com a psicanalista e teóloga Flávia Soldano Deheza, da Universidade Tres de Febrero, de Buenos Aires. 
a diferentes censuras. Estes enunciados se articulam num sistema relacional através de condensações e deslocamentos. O mecanismo de condensação é uma convergência que permite a similaridade de pensamentos, mas o núcleo do trabalho reside no deslocamento que transfere a intensidade dos elementos do sonho, o qual deforma as imagens e põe em primeiro plano o que tinha ficado para trás. Trata-se de um descentramento de sentido que o torna multivocal (FREUD, 2020).

Jacques Lacan, em sua reinterpretação da obra de Freud e influenciado pelo linguista Roman Jakobson, toma as figuras da condensação e do deslocamento para redefini-las como metáfora e metonímia (LACAN, 1984). A metáfora ou condensação é a substituição de um significante por outro, e esta substituição implica num aumento do sentido. A metonímia e uma combinatória horizontal, um deslizamento, uma analogia de significantes que tornam a metáfora possível (LACAN, 1957). Para o psicanalista francês, o sonho está estruturado como uma linguagem que se oferece, em seu trabalho, a uma escuta para que possa se tornar texto. Ou seja, uma estrutura significante elaborada com base em elementos que se combinam, que se substituem e que remetem a novos significantes, e não a um referente unívoco. Não somos donos de nossa fala, estamos presos na nossa rede de linguagem.

Nessas considerações, pretendemos levantar questões sobre uma relação entre linguagem do cinema e a religião que esteja preparada e até mesmo incentivada a se encontrar com labirintos de sentidos imersos nos jogos de condensação e de deslocamento na imagem cinematográfica. Cinema e religião não se comunicam diretamente, por equivalências diretas, nem por referentes comuns e transparentes com o real. Um filme e um texto religioso, para versarem sobre a realidade, precisam deformá-la. Um filme que interpreta a realidade por meio de símbolos religiosos o faz em processos de múltipla codificação, o que torna os aspectos acima mencionados ainda mais poderosos. Ao falarmos de cinema e literatura bíblica, estamos falando de labirinto dentro de outro labirinto?

\section{Cinema: espaço semiótico híbrido de articulação de sentido}

Nossa proposta também focará em outro aspecto da relação entre texto bíblico e cinema. Retomaremos a partir do ponto já apresentado acima, da diferença entre a organização do texto escrito, que é discreto, ou seja, formando imagens na mente do leitor na sequência da leitura, e o texto imagético, que é icônico, que apresenta os seus componentes de uma vez, requerendo outras formas de decodificação. Se, no texto, temos que observar as regras 
da sintaxe e as escolhas semânticas em ação, frase após frase, no filme nos deparamos com imagens complexas que nos mostram certas coisas, em certas disposições, a partir de certo ângulo, com variáveis como luz, cor, foco, etc. Se a imagem é cinematográfica, ou seja, está em movimento, temos que observar nela ainda o jogo dos movimentos da câmera com o dos objetos e personagens na tela. A esse quadro já bastante complexo se somam, no filme, os sons, as vozes, diálogos, música, ruídos do ambiente etc. Lotman (1978, p. 163) comenta sobre essas linguagens em ação no cinema:

Todas essas camadas semióticas [mensagens verbais, musicais, relações extratextuais etc.] formam uma montagem complexa, e suas relações mútuas produzem também efeitos de sentido. É esta capacidade do cinema para “absorver" os tipos mais variados de semiosis e os organizar num sistema único, que temos em vista ao falarmos do caráter sintético ou polifônico do cinema.

Portanto, uma cena de narrativa bíblica, de um texto escrito, não tem apenas analogias com a linguagem do cinema, com a qual estamos certamente habituados; na verdade, ela passa por profundas transformações em seus sistemas de codificação. Um filme é uma narrativa escrita transformada, codificada hibridamente, em imagens em movimento e sons que formam um novo e complexo texto.

Esses aspectos polifônicos e híbridos da linguagem cinematográfica devem ser considerados na análise dos filmes concretos, no intuito de abrir potenciais sentidos do texto bíblico. A análise pode ser conduzida dos aspectos mais técnicos, como foco e enquadramento, às características da montagem da narrativa cinematográfica. Segundo o diretor de cinema Serguei Eisenstein (2002), a força do cinema está na montagem das cenas, na forma como o trabalho do diretor organiza a narrativa e suas tensões a partir dos diferentes materiais, criando uma narrativa única, mas com partes de diversos focos da câmera. Na montagem, o diretor pode dar contraste, movimento, pode criar oposições dialéticas. Pensemos no trabalho de montagem de suas obras mestras, como "A Greve" (1924), “O Encouraçado Potenkin" (1925) ou "Outubro" (1927). Trata-se de um jeito imagético cinematográfico de organizar a narrativa, de inserir múltiplos ângulos, movimento, contrastes, de usar de eixos espaciais, de focar imagens, trazer ao destaque os grandes planos, como os rostos em close up, por exemplo. Da mesma forma, podemos imaginar como a montagem de um filme que recria cenas ou temas bíblicos, implícita ou explicitamente, com a técnica de montagem do filme, pode impactar na percepção e interpretação da narrativa bíblica, ativando nela sentidos potenciais. 
Não se trata, no entanto, apenas do uso de técnicas, sejam as de filmagem ou as de montagem (para citar apenas essas). Segundo Morin (2014), o cinema também permite jogos de projeção e identificação no espectador. A imagem cinematográfica tem um poder mágico de nos colocar em relação de "participação" com rostos e paisagens. Ele nomeia essa característica da experiência de cinema de "antropocosmogônica". Ou seja, imagens em movimento, por meio das quais podemos nos associar a imagens humanas e cósmicas, em processos de projeção e identificação. Aspectos mítico-mágicos de nossa psique profunda são ativados, nos conduzindo a uma experiência da profundidade e do poder de articulação análogo ao do sonho. Desta forma, a experiência semiótica híbrida e polissêmica se torna também uma experiência psíquica impactante. O cognitivo e semiótico, juntos, se articulam ao psíquico e sensorial. O sentido se torna experiência.

\section{A leitura fílmica do texto bíblico: uma análise narrativa a partir de Metropolis, de Fritz Lang}

Faremos agora uma análise do filme Metropolis, de 1927, dirigido por Fritz Lang, com o objetivo de mostrar aspectos da ativação de sentidos potenciais do texto bíblico na linguagem do cinema. Não pretendemos de forma alguma ser exaustivos, nos limitando a alguns aspectos do filme de relevância para nosso argumento. Também não abordaremos o contexto histórico da produção do filme, além do estritamente necessário. Recomendamos que, antes da leitura dos parágrafos a seguir, nossos leitores tenham assistido o filme, que está disponível na internet em versão restaurada. ${ }^{4}$

\section{O enredo de Metropolis}

\section{$A$ abertura:}

Após uma breve introdução com máquinas, engrenagens, a cidade, um relógio e um apito que marca a troca de turno, o filme se inicia com apresentação de dois mundos. Num mundo subterrâneo, na "cidade dos trabalhadores", operários caminham de forma mecânica e padronizada para a troca de turno. Os que saem estão esgotados e se dirigem para suas casas na igualmente subterrânea cidade dos trabalhadores. No outro mundo, o superior, no "clube dos filhos", os filhos das elites praticam esportes em amplos espaços, cercados de arquitetura grandiosa. Numa segunda cena Freder, filho

4 Metropolis, diretor Fritz Lang, 1927. Disponível em https://www.youtube.com/watch?v=Vnp TAb52AI. Acesso em 29 abr 2021. 
do diretor/governante/proprietário da cidade, está num jardim paradisíaco (o “jardim eterno”), com aves e plantas exóticas, um poço ao meio, em jogos eróticos com mulheres deslumbrantes.

\section{O encontro e tomada de consciência:}

Nesta cena se dá o encontro de Freder com uma jovem que cuida dos filhos dos trabalhadores, Maria, que adentra por engano no jardim e, portanto, é conduzida para fora. Ele fica impactado com ela e a busca nas instalações industriais subterrâneas. Nessa busca, ele presencia um acidente com vítimas, numa grande máquina. Ele tem uma visão na qual essa máquina é transformada numa espécie de pirâmide de Moloque, na qual são realizados sacrifícios humanos, cujas vítimas eram os operários. Acontece, em seguida, uma primeira visão da grande cidade futurística: Metropolis.

\section{Recorrer ao pai:}

Em desespero, Freder recorre a seu pai, Joh Fredersen, que dirige $\mathrm{Me-}$ tropolis do alto de um edifício imponente no centro da cidade. O filho relata o ocorrido. O pai fica furioso ao não saber disso e também de um plano de sedição dos trabalhadores, pela boca de seu assistente Josaphat. O pai demite Josaphat, que teria que ir ao mundo subterrâneo, e encarrega um vigia (Der Schmale, "o cara") de seguir os passos de seu filho.

\section{Retorno às profundezas:}

Freder quer saber mais sobre o que se passa no mundo subterrâneo. Lá ele troca de lugar com o funcionário chamado 11811 Georgy, e passa a operar em seu lugar a máquina central. 11811, por sua vez, vestido como Freder e passando-se por ele, pede ao motorista que o leve ao clube noturno das elites, Yoshiwara. O pai de Freder visita um rival, o inventor Rotwang, que lhe relata seu plano de dar vida novamente à mulher que ele amava, a falecida esposa de Fredersen, que morrera dando à luz a Freder. Ela reviveria no robô Hel.

\section{Descida de Freder à catacumba:}

Freder descobre o plano de sedição dos trabalhadores contra seu pai e resolve se juntar aos rebeldes numa reunião que aconteceria numa catacumba, vestido como operário. Essa reunião é liderada por Maria, que lidera os trabalhadores. Ela lhes narra a história da Torre de Babel e lhes anuncia a chegada de um Mediador. Fredersen e Rotwang espiam a cena escondidos. Freder se apresenta a Maria e admite assumir o papel do Mediador. Ambos se apaixonam e prometem se reencontrar. Fredersen, o pai, pede que Rotwang 
execute seu plano de criar a robô Hel, mas que ela tenha o rosto de Maria, para assim jogar os trabalhadores contra ela.

\section{Perseguição e rapto de Maria:}

Maria é perseguida na catacumba e raptada por Rotwang. Freder entra numa igreja em que um religioso prega: "O tempo do Apocalipse está próximo". Ele tem uma primeira visão do livro do Apocalipse, do texto sobre a Grande Babilônia e o rosto de Hel. Freder tenta resgatar Maria em vão. Ela tem seu rosto copiado e transferido para Hel. Rotwang envia Hel imediatamente para Fredersen, para destruir a cidade. Por sua vez, Fredersen quer destruir os trabalhadores e seu movimento com essa falsa Maria.

\section{A manifestação de Hel e sua dança:}

Freder é colocado em custódia pelo pai, sob vigilância do Schmale. Ele fica enfermo e tem uma visão em delírio: Hel dança como a mulher do Apocalipse 17, sob os olhos dos 100 homens mais importantes do mundo. O Schmale prega de um púlpito e levanta uma Bíblia, em que o texto do Apocalipse 17 é mostrado. Em seu sonho também aparece a morte ceifando entre os sete pecados capitais.

\section{Conflitos e rebelião:}

Os 100 homens mais importantes brigam e se matam entre si por Hel, que dança e novamente é identificada com a Grande Prostituta. Freder desce novamente à catacumba para uma nova reunião dos trabalhadores com Maria. Mas quem os comanda é Hel, em aparência de Maria. Hel lança os trabalhadores contra o Mediador. O duplo de Freder, 11811 Georgy, é assassinado. Incitados por Hel, os trabalhadores destroem a Máquina-Coração (a Herz-Machine), mesmo sabendo que isso destruirá a cidade deles.

\section{O resgate das crianças:}

Com a destruição da máquina, a cidade subterrânea começa a ser inundada. Freder e Josaphat descem para a cidade dos trabalhadores. Maria, que foge de Rotwang, se une a eles e lidera o resgate dos filhos dos trabalhadores da enchente. Eles conduzem as crianças para cima por escadas apertadas e íngremes.

\section{A cena final:}

Após os operários se lembrarem de seus filhos, buscam a culpada por tudo, aquela que os incitou à destruição da Máquina. Eles queimam Hel, 
mas só então descobrem se tratar de um androide. Rotwang persegue Maria até o telhado da catedral. Freder luta contra Rotwang e o vence. O povo marcha até a porta da catedral. O líder dos trabalhadores e Fredersen relutam em estenderem as mãos e selarem a paz. Freder os encoraja e os faz se cumprimentarem. Maria repete o refrão do filme: "Cérebro e mãos querem se encontrar, mas lhes falta o coração para isso. Mediador, tu, mostra-lhes o caminho de um ao outro".

\section{Os eixos e niveis mito-poéticos em Metropolis}

Como pudemos observar, apesar de Metropolis ser um filme de ficção científica - na verdade, o primeiro deles - e propor uma crítica à sociedade industrial, regida pelo grande capital e estruturada em torno de máquinas, ele recorre a estruturas mito-poéticas. Essa é uma característica do cinema que já havia sido observada por Eisenstein. Segundo ele (EISENSTEIN, 2002), necessitamos da potência da linguagem do mito para transformar nosso presente e futuro, e das estruturas sensoriais, primitivas, para representar a realidade e propor a sua transformação. Também devemos observar que, apesar de não ser um filme de enredo bíblico do passado, o filme é tomado por referências intertextuais implícitas e explícitas aos textos bíblicos. De fato, há uma pequena cena em que é reencenada, num filme dentro filme, a história da Torre de Babel. Maria interpreta aos trabalhadores o mundo de opressão em que vivem em Metropolis, narrando a história da construção da torre. A forma como a cena da Torre de Babel é apresentada chega a ser até caricata e estilizada, de tão explícita. Nesse sentido, poderíamos dizer que Metropolis seria uma releitura do Gênesis 11.

No entanto, são as três imagens explícitas do texto do Apocalipse que parecem estruturar a parte central do filme. Observem que não se trata de falar sobre o Apocalipse ou de fazer citações do texto apenas: o próprio livro é mostrado, aberto, com seu texto legível, focando na "Grande Prostituta Babel". Numa das vezes, a imagem é tão plasticamente enfática que a página aberta é de uma Bíblia iluminada, com texto (legível) e iluminura da mulher sentada sobre o monstro bem visíveis por alguns segundos. Trata-se de uma dupla exposição do capítulo 17, associado à dança de Hel. O texto do Apocalipse, além de todas as referências e alusões de que é objeto, é mostrado 3 vezes. Nesse sentido, o filme propõe uma leitura quase que alegórica do texto bíblico: os 100 homens mais ricos e poderosos equivaleriam aos 10 reis aliados a Babel, a destruição de Hel equivaleria à destruição de Babel etc. 
Há outros elementos bíblicos no texto que não podem passar despercebidos. Um deles é a inversão do paraíso do Gênesis no começo do filme, quando Freder está num jardim exótico se divertindo com mulheres exuberantes. Ele brinca com uma delas, perseguindo-a ao redor de uma fonte. Jardim paradisíaco e fonte são imagens presentes tanto no Gênesis quanto no Apocalipse. Encontramos outra referência ao primeiro livro da Bíblia na cena da enchente que inunda a cidade dos trabalhadores e que ameaça a vida de seus filhos. Trata-se de uma alusão à narrativa do dilúvio. Por fim, nos remete ao Antigo Testamento o delírio/visão de Freder, que enxerga no acidente da máquina, que vitima trabalhadores, sacrifícios humanos dedicados ao deus Moloque. Voltando ao Apocalipse de João, a cena em que os trabalhadores descem à catacumba para encontrarem com Maria nos lembra a inversão do movimento descida - subida, no qual se encontram com uma mulher entre velas. Seria uma referência deslocada e invertida da visão da mulher do Apocalipse 12?

Como vimos acima, o filme Metropolis é estruturado em torno de elementos narrativos e simbólicos da narrativa bíblica. Não é um filme bíblico. Pelo contrário, elabora uma crítica contundente à sociedade moderna, à sua tecnologia, modos de produção, estratificação social e opressão dos trabalhadores. Sua mensagem final é de que uma profunda mediação entre capital e trabalho se faz necessária e urgente. Ainda que a narrativa tenha uma rebelião - que evoca cenas de revolução - a proposta do filme não é socialista. Na cena final, os trabalhadores caminham lenta e mecanicamente rumo à entrada da catedral para se encontrarem com Fredersen, o patrão. A transformação das relações se dá no aperto de mão, inicialmente relutante, entre o encarregado das máquinas e Fredersen, mediados por Freder, o Mediador. Mas, diferentemente do filme soviético "Outubro", a revolta de Metropolis não muda as relações sociais. Elas serão humanizadas, mediadas, harmonizadas, mas seguirão tradicionais. Esse final surpreendente nos coloca no contexto dos dilemas do início de século $\mathrm{XX}$, em que havia grande descontentamento com as relações sociais derivadas da exploração do trabalho pelo capitalismo, mas que rejeitavam a solução revolucionária socialista. Dentre essas várias buscas por alternativas estava a emergência dos diferentes fascismos na Europa. Como Metropolis se relaciona com eles é uma questão que não podemos responder nesse breve artigo.

\section{A leitura bíblica de Metropolis}

Chega o momento de nos propormos a questão que motiva nosso ensaio, a saber: como Metropolis se articula como um espaço artístico de 
interpretação do texto bíblico. Não há dúvidas de que o filme é estruturado por meio das cenas bíblicas, principalmente a de Gênesis 11 e de Apocalipse 17. Queremos saber se o filme "abre" o texto, se permite que, em nosso processo de leitura (de visualização) do filme, novos sentidos potenciais do texto sejam atualizados.

Sem pretensões de definir os procedimentos de análise de filmes, podemos organizar nossas observações na seguinte sequência: a) que textos são escolhidos, em que sequência são bricolados? b) Com que aspectos religiosos ou mito-poéticos não bíblicos o filme associa o material bíblico? c) Com que âmbitos da realidade do filme (da realidade do mundo do filme) os textos são relacionados? d) Quais são os movimentos mito-poéticos fundamentais da narrativa? Ofereceremos respostas preliminares a essas questões para evidenciar novos olhares que o filme permite lançarmos sobre a Bíblia. Ficarão de fora questões igualmente importantes, como aquelas referentes à técnica cinematográfica. O enquadramento, o foco, a montagem, a iluminação, etc. É por meio delas que o cinema faz interpretação de mundo. Por isso, o trabalho de análise de filmes e religião só pode ser bem sucedido se realizado de forma interdisciplinar. Este artigo tem que ser, portanto, complementado com essa análise.

Metropolis estrutura sua narrativa em torno de uma criativa combinação de elementos do Gênesis e do Apocalipse. No começo do filme, há uma cena paradisíaca invertida, em que Freder é servido por cortesãs em um jardim (“o jardim eterno”) com plantas e aves exóticas, brincando jogos eróticos ao redor de um poço. De fato, ele não pode ser o jardim paradisíaco e só pode desempenhar um papel na narrativa na inversão de seu tema: é um falso paraíso. Isso é expresso pelo velho funcionário que guia as jovens acompanhantes em seus gestos, o que tira qualquer espontaneidade erótica da cena. Também se revela um falso jardim quando entra Maria com as crianças, num lugar que lhes é proibido, e aponta para aqueles jovens de elite e lhes diz que ali estão seus irmãos. Esse jardim não é lugar para Maria e seus pequenos acompanhantes. Eles são conduzidos para fora dali pelo elevador, são conduzidos para baixo. Adiante falaremos mais sobre esses elevadores, que desempenham um papel condutor da narrativa. Elementos do Gênesis também são determinantes na história da Torre de Babel, que Maria conta aos trabalhadores na catacumba. Nessa parte temos uma das "citações" bíblicas mais explícitas do filme, em que o relato de Gênesis 11 é encenado, de forma caricata. Por fim, o Gênesis reaparece mais uma vez na narrativa, ainda que de forma indireta, na cena em que a cidade dos trabalhadores começa a ser inundada após a destruição da Máquina Coração (Herz-Maschine). Temos aqui uma retomada deslocada da história do dilúvio. 
Enquadrada por esses elementos do primeiro livro da Escritura, encontramos três citações explícitas do Apocalipse. Elas acontecem de uma forma criativamente explícita: o próprio livro é mostrado, aberto, legível. Na última vez que aparece, há um ápice, uma vez que texto e iluminura são enquadrados na imagem. O texto é o complexo do Apocalipse 17 e 18, no qual a crítica ao poder político opressor, Babilônia - Roma, é feita com imagens de uma mulher prostituta, rica, embriagada de sangue dos justos, assentada sobre um monstro escatológico e cercada por seus admirados aliados. Acompanham as três aparições do livro as imagens de Hel, que aparece de dentro de uma grande taça, primeiro carregada por homens negros, que são transformados em estátuas e, por fim, transformados no monstro de sete cabeças. Hel dança frenética e eroticamente sobre ele; primeiro, diante dos extasiados 100 homens mais poderosos do mundo, que a desejam ardentemente, mas que depois guerreiam entre si, em disputa e em compulsões suicidas por causa do acesso a seu objeto de desejo. Desta forma, o filme estabelece relações entre Metropolis, Hel, o poder financeiro e político de sua elite, o mundo masculino da casa noturna Yoshiwara, numa conjunção entre poder financeiro e erotismo. Essa associação de símbolos é cimentada pelas imagens ancestrais do Apocalipse e por suas associações entre a grande cidade, Babel, a prostituta, o monstro e seus aliados. Violência, poder, dinheiro, desejo sexual masculino e o feminino demonizado são conjugados e potencializados nesse duplo nível de associações.

O fato de imagens e narrativas do Gênesis e do Apocalipse serem combinadas no filme não deve nos surpreender. Já foi observado por estudiosos que há uma relação entre tempo primordial (Uræeit) e tempo escatológico (Endžeit), e que Gênesis e Apocalipse e seu simbolismo mítico, dos extremos do cânon cristão, apontam um ao outro, configurando assim um campo de conflito cósmico (GUNKEL, 1895). O Apocalipse pode, dessa forma, ser interpretado como uma releitura do Gênesis. Não por acaso, ele também termina com um jardim. No filme, a justaposição de temas do Gênesis e do Apocalipse, mais especificamente, o enquadramento dos temas do Apocalipse pelos do Gênesis (Paraíso/jardim, Torre de Babel - três referências ao texto do Apocalipse 17 - dilúvio) parece sugerir que não se trata apenas de uma narrativa sobre o fim dos tempos - como se isso fosse pouco -, mas também um relato mítico que combina os temas da fundação do mundo e do seu esgotamento escatológico para fazer emergir a crise de Metropolis, a cidade tecnocrática, em suas contradições profundas. Apelar a imagens e enredos do tempo primordial e do tempo escatológico, articulando-os, é uma forma poderosa de escancarar o caos instaurado pelo mundo que se denuncia. Estas 
relações de produção e estratificação social são desenhadas diante dos espectadores com as imagens mais potentes de que dispõe a tradição bíblica. No centro desse arsenal simbólico está a imagem da cidade Babel: a do Gênesis, em seu projeto opressor e impossível, fadado ao fracasso, e do Apocalipse, da cidade prostituta vitimadora de seus trabalhadores.

Essas imagens bíblicas são potencializadas por outras que as acompanham. Algumas não procedem da Bíblia, mas fazem parte de sua história de interpretação. Uma delas é a apresentação do céu onde se encontra Maria na viagem invertida do mundo dos mortos, a catacumba. É nesse mundo dos mortos que os operários se encontram com Maria, num altar iluminado por velas. É ali que se dá a revelação do Mediador, e o primeiro encontro dos amantes. Quando Rotwang persegue Maria na catacumba, há um jogo fascinante de luz e escuridão. Incialmente, as luzes são das velas, símbolo de revelação espiritual, mas habilmente, durante a perseguição, com a introdução da lanterna de Rotwang, segurada por sua mão de metal, a luz se torna violenta, opressora, focando com seu brilho frio e intimidador o rosto assustado de Maria. Essa caverna se torna um microcosmo, um labirinto que representa o labirinto subterrâneo que é o mundo dos homens e mulheres de Metropolis. A catacumba corresponde à cidade dos trabalhadores, um espaço de morte. Também destacamos a cena, inicialmente gratuita, da passagem de Freder pela catedral, após sair do primeiro encontro com Maria na catacumba. Ele adentra na igreja e ouve um religioso pregar: "o tempo do Apocalipse chegou”. Em seguida, uma cena mostra estátuas dos sete pecados capitais, com a morte ao centro. Essa relação dos pecados capitais e a morte com o Apocalipse de João é um tema da interpretação medieval deste livro. Dá um tom moralizante ao final dos tempos e o relaciona com a escatologia individual: o juízo final representado na colheita pela foice da morte. No delírio/sonho que Freder tem com a pregação do Schmale, em que ele levanta o texto e a imagem da passagem de Apocalipse 17, o filme nos mostra a dança de Maria, os olhares lascivos dos homens poderosos e, como ápice, retoma essa cena. Nela, a morte se destaca dos sete pecados capitais e caminha em direção ao espectador, balançando sua foice até o golpe final.

Metropolis, como um filme apocalíptico, é enciclopédido. Os apocalipses narram o todo, a partir de suas imagens e símbolos centrais. Esse é o jogo do filme: fazer uma interpretação de toda a sociedade. Por isso estabelece com clareza os cenários: abaixo, as fábricas subterrâneas, a insossa cidade dos trabalhadores; acima, a cidade dos filhos, jardins, estádios monumentais, e Metropolis. A cidade é mostrada como um espaço futurista, no qual se destacam prédios e vias imensas. O dinamismo não é dado por pessoas, mas sim 
por meios de transportes: automóveis, trens, aviões, dirigíveis. Trata-se de uma representação futurista do mundo das metrópoles modernas. Podemos imaginar o impacto que a primeira apresentação de Metropolis deve ter causado entre os primeiros espectadores. Que cidade fascinante e assustadoramente perturbadora seria essa, cidade que aponta para as nossas cidades? O mundo das máquinas é o mundo da produção; produção que tem seus efeitos nos números anotados freneticamente pelos assessores de Fredersen, no alto do edifício central da cidade. É para esses números que o restante da estrutura opressiva de trabalho existe. Das máquinas operadas por exaustos corpos humanos para aqueles dados abstratos e frios. Embaixo, há máquinas operando, corpos submetidos a trabalho extenuante. Corpos que na alucinação/visão de Freder são oferecidos na máquina como sacrifícios humanos a Moloque. O controle dos corpos ocorre num ritmo frenético, mecânico e com a precisão do relógio. Várias vezes podemos "ouvir" o apito da troca de turnos. O tempo também é controlado pelo relógio de 10 horas, inicialmente operado por 11811 Georgy, depois pelo próprio Freder. Esse tempo da produção só pode correr com a cooperação sofrida dos corpos humanos. É um tempo da máquina, da produção. E para falar de máquinas e números, o filme lança mão de narrativas e esquemas imagéticos ancestrais. Para expressar essa relação claustrofóbica da produção e do controle do tempo na cidade subterrânea dos trabalhadores, Metropolis é organizado por meio de eixos mito-poéticos que estruturam sua narrativa. Esses são os elementos que estão na base de toda a articulação de sentido do filme, que dão potência e polissemia às imagens. É o recurso a essas estruturas que faz com que a crítica à modernidade industrial capitalista de Metropolis seja muito mais do que um panfleto datado, podendo ser relida em nosso mundo, quase 100 anos depois. Esses elementos simbólicos são arcaicos, estão na base da cultura e estruturam a linguagem do mito, são os primeiros elementos espaço-temporais que nos permitem perceber nossos corpos no mundo, num mundo humanamente ordenado.

Dentre as estruturas simbólicas que Metropolis se utiliza há uma básica, aquela que nos permite ver o mundo, ver o mundo na tela do filme: as imagens dos estados da alma. As percepções importantes de mundo de Metropolis, naquelas cenas centrais para a interpretação da realidade nas lentes do filme, são moldadas por delírios, sonhos e visões. É num delírio que Freder percebe o caráter sacrificial da relação dos homens com a máquina, quando tem a visão dos trabalhadores sendo entregues na estrutura industrial, representada como uma pirâmide, em sacrifícios humanos a Moloque. Sem essa cena, toda a nossa percepção do mundo das máquinas e engrenagens teria sido empobrecida. Há, também, ao menos outros dois delírios no filme. O 
primeiro é de ordem edípica, quando Freder vê Hel junto ao pai. Ele toma Hel por Maria e desmaia. Em decorrência disso, ele é enviado por seu pai a seu apartamento, onde é vigiado pelo Schmale. Ali ele tem mais um delírio/ sonho, o mais importante do filme, no qual vê Hel (que crê ser Maria?), como a grande prostituta dançando sobre o dragão, diante dos poderosos. Nesse delírio/sonho é que ele vê o texto bíblico sendo levantado, aberto em Apocalipse 17, e nele se manifesta a morte ceifando vidas. Trata-se de um delírio que produz revelação. A identidade verdadeira de Metropolis é revelada na identidade falsa do duplo de Maria, que é Hel. Esses delírios e sonhos permitem que o filme transgrida as percepções correntes e as eleve ao nível das associações mito-poéticas. Nesse sentido, podemos dizer que todo o filme é organizado na linguagem do sonho, com as suas formas dinâmicas de conexão entre imagens aparentemente incompatíveis, mas que criam um todo complexo e denso de sentido. Talvez possamos dizer que esse seja mais um elemento que as imagens em movimento de Metropolis evocam da experiência do Apocalipse: um ver imagens incomuns, bizarras e grotescas, condensadas e deslocadas, mas que transfiguram o presente, inserindo-o em um combate de forças primordiais que determinam as vidas humanas. As visões arcaicas do filme futurista, de ficção científica, se tornam revelação.

Além desses elementos simbólicos e narrativos, explícita e implicitamente bíblicos, há outras imagens de ordem religiosa no texto, que não necessariamente provêm da narrativa bíblica, mas ajudam a estruturar a narrativa. Há uma certa ênfase, no filme, no caráter simbólico de partes do corpo humano. Este é o caso da ênfase no coração, seja como metáfora ou como imagem. O coração é o lugar da mediação, do encontro, entre mãos e cérebro, ou seja, entre trabalhadores e líderes. A primeira parte do corpo de Hel a funcionar, quando acionado eletricamente, é o coração pulsante. A mão também recebe destaque. No encontro entre Freder e Maria há uma comunicação das mãos que se tocam afetuosamente. Por outro lado, há um claro contraste entre as mãos delicadas de Maria e a mão mecânica de Rotwang na cena da perseguição da catacumba. Por fim, há uma expressão dos olhos que marca as identidades dos personagens e que distingue os duplos. Esse é o caso do olhar sempre cândido de Maria e o olhar malicioso de Hel. O olho direito de Hel sempre fica caído, como que sinalizando maliciosamente. Também há um efeito cinematográfico de destaque ao olhar, quando os olhos dos homens poderosos que desejam a dançante Hel são multiplicados na tela. O corpo e suas partes, assim como certos objetos e paisagens, tem o poder de simbolizar, de servir de espaços de projeção. Em contraste com coração, mãos e olhos, estão as máquinas, em profusão. $\mathrm{O}$ filme se inicia mostrando 
engrenagens e roldanas. Todo o espaço de trabalho dos homens e mulheres é rodeado de máquinas das mais diversas. O ritmo alucinado das máquinas contrasta com o cansaço e uniformização dos corpos humanos. Mas, ainda que as máquinas dominem, elas precisam da ação dos homens, de seu ritmo, coordenação. Essa relação tensa e opressiva da máquina com os corpos humanos fica mais evidente na cena em que Freder troca de lugar com 11811 Georgy, passando a coordenar o funcionamento da máquina central, ao acertar ponteiros de um relógio enorme de 10 horas. Em alguns momentos, os braços de Freder ficam abertos, formando com o restante de seu corpo uma cruz. Nessa luta contra a máquina, ele clama, de braços abertos, como um Cristo crucificado: "Pai! pai! Nunca acabam essas dez horas?".

Por fim, destacamos a organização do filme em torno do eixo espacial da ascensão e do descenso. No filme, se sobe e desce o tempo todo. $\mathrm{Na}$ primeira cena, nos deparamos com a troca do turno dos trabalhadores. Eles entram e saem de enormes elevadores, que os levam para o trabalho ou para casa. Quando Maria adentra equivocadamente no jardim, na cidade dos filhos, ela o acessa também por meio de um elevador. O elemento de ascensão e descenso predomina nas duas cenas que acontecem na catacumba. O laboratório de Rotwang também é um laboratório com muitas portas e escadas, por onde se sobe e desce. Na cena em que Freder e Josaphat descem para resgatar as crianças, eles descem por atalhos e túneis. Por fim, quando eles e Maria salvam as crianças, o fazem subindo íngremes escadas. Na última cena, Rotwang rapta Maria e a leva até o telhado da catedral. É lá que ele e Freder se enfrentam, com a morte do primeiro. A verticalidade de Metropolis é um eixo mito-poético que remete às estruturações arcaicas do espaço, é também nesse eixo que se estrutura a imagética dos Apocalipses antigos, nos quais se ascende aos céus para contemplar o mundo divino ou se desce ao mundo infernal para ver os horrores que ali predominam. No caso de Metropolis, essa organização vertical dos espaços serve para ressignificar deslocada e invertidamente o espaço superior como paródia do mundo divino. Esse subir não é divino, não conduz à luz verdadeira. É lá que Fredersen, como um juiz poderoso, condena Josaphat por ter falhado na administração da cidade para que seja expulso da cidade e enviado à cidade inferior, a dos trabalhadores. E lá encontramos diferentes níveis e câmaras, como nos infernos cristãos da antiguidade tardia e medievais. Curiosamente, seguindo o modelo de deslocamento e de inversão, é no mundo subterrâneo, na catacumba, que se dá a revelação, que Freder e Maria se encontram, que se descobrem amantes e que assumem sua missão de reconciliar o mundo. 


\section{Considerações finais}

Neste ensaio, oferecemos reflexões sobre o papel que a análise de filmes que abordam temas, cenas e narrativas bíblicas pode ter para nos abrir a compreensão dos textos bíblicos. Propomos, portanto, que os processos de interpretação não tenham apenas uma mão única, do texto antigo, original, em direção à recepção, no caso, para a releitura cinematográfica. Entendemos que a linguagem cinematográfica, com uma analogia com o mundo do sonho - e, nesse sentido, da religião! - e por seu caráter semioticamente híbrido, abre possibilidades de ativar os sentidos potenciais dos textos. Analisar filmes seria, nessa perspectiva, não apenas um exercício especializado, ou até mesmo nerd. Ao contrário, é uma forma de possibilitar novas leituras bíblicas em tempos de reprodução técnica digital e imagética da religião. Talvez possamos acessar estruturas profundas de nossa psique e renovadas compreensões dos textos antigos, quase domesticados, por meio das provocações das imagens em movimento.

\section{Referências bibliográficas}

AICHELE, G. et al. The postmodern Bible. The bible and culture collective. Hew Heaven: Yale University Press, 1995.

BURNETTE-BLETSCH, Rhonda (ed.). The Bible in motion: a handbook of the Bible and its reception in film. Part 1. Berlin: Walter de Gruyter, 2016.

EISENSTEIN, Sergei. A forma do filme. Rio de Janeiro: Zahar, 2002.

EXUM, J. Cheryl (ed.). The Bible in film. The Bible and film. Leiden: Brill, 2006.

FREUD, Sigmund. A interpretação dos sonhos. São Paulo: Companhia das Letras, 2020.

GUNKEL, Hermann. Schöpfung und chaos in Uržeit and Endz̧eit. eine religionsgeschichtliche Untersuchung über Gen 1 un Ap Joh 12. Göttingen: Vandenhoeck \& Ruprecht, 1895.

LACAN, Jacques. El seminario. Libro V: Las formaciones del inconsciente. Buenos Aires: Paidós, 1957-1958.

LACAN, Jacques. El seminario. Libro XX. Buenos Aires: Paidós, 1998.

LOTMAN, Y. Estética e semiótica do cinema. Lisboa: Editorial Estampa, 1978.

MORIN, Edgar. O cinema ou o homem imaginário. Ensaio de antropologia sociológica. São Paulo: É Realizações, 2014.

NOGUEIRA, Paulo A. S. O conceito de texto, contexto e leitor na interpretação de textos religiosos: o caso da literatura bíblica. Estudos de Religião, São Bernardo do Campo, v. 33, n. 3, p. 175-190, set.-dez. 2019.

REINHARDT, Adele (ed.). Bible and cinema: fifty key films. London: Routledge, 2013.

SHEPHERD, D. (ed.). Images of the world: Hollywood's Bible and beyond. (SBL Semeia Studies, vol. 54). Leiden: Brill, 2008.

YAMASAKI, Gary. Insights from filmmaking for analyzing biblical narrative. (Insights: Reading the Bible in the $21^{\text {st }}$ Century). Minneapolis: Fortress Press, 2016. 